\title{
安水活性污泥処理工程における排水中微量要硝酸イオン, 硝酸イオン濃度の連続測定システム
}

\author{
松本龍太郎* ·小野 昭紘 ${ }^{* 2} \cdot$ 井幡 忠 ${ }^{* 3} \cdot$ 植村 健 ${ }^{* 3}$
}

\author{
An Analytical System for Measuring Continuously Concentration \\ of Trace Amounts of Nitrite and Nitrate Ions in the Activated \\ Sludge Aeration Bath for Ammonia Liquor Treatment
}

Ryutaro Matsumoto, Akihiro Ono, Tadashi Iвata, and Takeshi Uemura

\begin{abstract}
Synopsis:
A new analytical system for measuring continuously concentration of trace amounts of nitrite and nitrate ions in the activated sludge aeration bath for treatment of ammonia liquor discharged from coke oven, has been developed. The developed system is based on the principle that nitrite and nitrate ions are spectrophotometrically determined at $355 \mathrm{~nm}$ and $302 \mathrm{~nm}$, respectively, in the ultraviolet region after elimination of co-existing activated sludge and interferring materials. The proposed system are performed as follows: Sample solution taken from the aeration bath is subjected to centrifugal separation to eliminate the co-existing sludge. And then supernatant solution is passed through activated charcoal column to remove interferring colored materials. Subsequently, the solution is passed through anion exchange column for concentrating nitrite and nitrate ions. The both ions eluted separately from the anion exchange column by sodium chloride solution, are spectrophotometrically determined by ultraviolet detector. Down to $0.1 \mathrm{ppm}$ and $1 \mathrm{ppm}$ of nitrite and nitrate ions, respectively, can be simultaneously measured. The analytical results are automatically given once in every 10 minutes. The results agree well with those obtained by the manual method. The developed system is well applied to the ammonia liquor treatment process.
\end{abstract}

\section{1. 緒言}

コークス製造丁程で発牛する安水などの排水は，フェ ノールや油分類等を多荲含むために活性污泥による生物 学的処理を行つたの坊流している。しかし，この活性 污泥処理は種々の要因による影響を受けやすく, 処理操 業は必ずしも常時安”之しているとはいえない。活性污泥 処理操業の不調原因を調䍒した結果, その主な原因とし て硝化菌增殖現象が見いだされた。これは活性污泥曝気 槽中の溶存酸素濃度が槀すぎる場合に, 硝化菌が西硝酸 イオン $\left(\mathrm{NO}_{2}^{-}\right)$, 硝酸イオン $\left(\mathrm{NO}_{3}^{-}\right)$を生成して蓄積 し, COD 資化菌の機能を阻青するなどして活性污泥処 理を不調にするものである。
以上のよらな背景から，硝化菌増殖による安水処理の 不調をすみやかに察知して安定した処理操業を行らため に，活性污泥儤気槽中に生成する $0.1 \mathrm{ppm}$ 程度までの 微量の $\mathrm{NO}_{2}-$ 及び $\mathrm{NO}_{3}$ - 濃度を連続測定する必要が生 じた.

これまで排水中の $\mathrm{NO}_{2}^{-}$及び $\mathrm{NO}_{3}-$ の分析には， $\alpha$ ナフチルアミンスルファニル酸法1), ブルシンスルファ ニル酸法1) あるいはデバルダ合金還元蒸留法1) が一般的 に採用され，またこれらの化学分析法を基本とする テクニコンオートアナライザーを用いる方法2）も検討さ れている。しかし，これらのいずれの方法も安水試料中 の濁り, 着色, 共存成分等の影響を受けて定量精度が悪 く，連続測定方法として適用することは困難であつた.

昭和 54 年 10 月口本分析化学会 第 28 年会にて発表 昭和 55 年 7 月 21 日受付 (Received July 21, 1980)

* 新月本製鉄 (株) 基礎研究所 (Fundamental Research Laboratories, Nippon Steel Corp.)

*2 新H本製鉄 (株) 基礎研究所 理博 (Fundamental Research Laboratories, Nippon Steel Corp., 1618 Ida Nakahara-ku Kawasaki 211)

*3 新日本製鉄 (妳) 広畑製鉄所 (Hirohata Works, Nippon Steel Corp.) 
そこで，活性炭及びイオン交換処理によつて共存成分 等の分離及び $\mathrm{NO}_{2}{ }^{-}, \mathrm{NO}_{3}-$ の濃縮を行い, 発色操作を 行わずに直接紫外吸収を測定する新しい連続測定方法に ついて検討した.

\section{2. 試}

\section{薬}

(1) 標準严硝酸イオン溶 液 $\left(1000 \mu \mathrm{g} \mathrm{NO} \mathrm{N}^{-} / \mathrm{ml}\right.$ ) $105 \sim 110^{\circ} \mathrm{G}$ で約 4 時間乾燥し，デシケーター中で放冷 した亜硝酸ナトリウム $1.50 \mathrm{~g}$ をはかりとつて水に溶解 し，水を加古正確に $1 l$ にする.

(2) 標準硝酸イオン溶液 $\left(1000 \mu \mathrm{g} \mathrm{NO}{ }^{-} / \mathrm{ml}\right) 105$ $\sim 110^{\circ} \mathrm{C}$ で約 $4 \mathrm{~h}$ 乾燥し, デシケーター中で放冷した 硝酸カリウム $1.65 \mathrm{~g}$ を正しくはかりとつて水に溶解し， 水を加え正確に $1 l$ にする.

(3) 塩酸 $\alpha$-ナフチルアミン溶液 塩酸 $\alpha$-ナフチル アミン $0.3 \mathrm{~g}$ を塩酸 $(1+1) 5 \mathrm{ml}$ を含む水 $50 \mathrm{ml}$ で溶 解する. この溶液に, 酢酸ナトリウム ( 3 水塩) $10 \mathrm{~g}$ を 水約 $100 \mathrm{~m} l$ に溶解して承酢酸 $30 \mathrm{~m} l$ を加えた溶液をか きまぜながら混合し，水で液量を $250 \mathrm{~m} l$ にする.

（4）スルファニル酸溶液 スルファニル酸 $0.6 \mathrm{~g}$ を 温水 $70 \mathrm{~m} l$ に溶解し, 冷却後, 塩酸 $20 \mathrm{~m} l$ を加之, 水で $100 \mathrm{~m} l$ にする。

（5） スルファニルアミド混合溶液 スルファニルア ミド $3.33 \mathrm{~g}$ を塩酸 $(1+1) 10 \mathrm{ml}$ 及び水 $50 \mathrm{ml}$ を加え て溶解する．この溶液を，酢酸ナトリウム（ 3 水塩） 500 $\mathrm{g}$ を水 $400 \mathrm{~m} l$ に溶解した溶液に加え, 酢酸または水酸 化ナトリウム溶液によつて $\mathrm{pH} 7 \pm 0.1$ に調節したのた， 水で全量を $1 l$ にする.

(6) ナフチルェチレンジアミン溶液 N-(1-ナフチ ル)ーエチレンジアミン 2 塩酸塩 $0.1 \mathrm{~g}$ を水 $100 \mathrm{ml}$ に溶 解する。

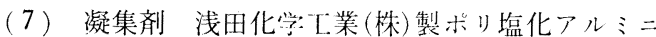
ウム溶液（ポリ塩化アルミニウム $10 \%$ ，硫酸塩 $2.65 \%$, 塩基度 $49.8 \%$, 比重 1.24 ) を水で 5 倍に希釈する.

（8）溶離液 塩化ナトリウム $50 \mathrm{~g}$ を水で溶解し， 水を加えて $1 l$ にする.

（9）粉末活性炭 第一苂素工業製椰子殼粉末活性 炭, FM-150.

(10) 粒状活性炭 只羽化兴製石油系球状活性炭，只 羽ビーズ-SP, $250 \sim 350 \mu \mathrm{m}$.

(11) 陰イオン交換樹脂 Bio Rad Laboratories 製, AG $1 \times 4,<37 \mu \mathrm{m}, \mathrm{Cl}$ 型.

\section{3. 手操作による標準分析方法}

安水試料の活性炭処理やイイン交換濃縮等の基礎実験
及び確立した自動分析法の正確さの確涩に必㛄となる

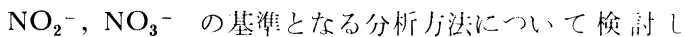
た。安水試料は汗泥を含及，末た，其你成分に占つて黄

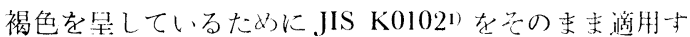
ることは困難であつた。元こで４．で述べる㛟讨結 果などから，荌水武料を活州:炭で処理したのたに，JIS

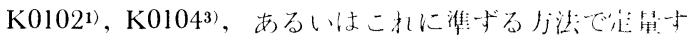
る下記分析方法を分めた。

\section{$3.1 \mathrm{NO}_{2}-$ 標準分析方法操作}

(1) 活性污泥曝気槽から安水武料を採收 L, 自七, に 遠心分離を行い，大部分の污泥を分離除上小を。

（2）污泥を除去したは澄液 $100 \mathrm{ml}$ をビーカー(200 $\mathrm{ml}$ ) に移し，塩化ナトリウ人 $1.5 \mathrm{~g}$ を加えて溶解し，粉 末活性炭約 $2 \mathrm{~g}$ を加えてがラ久棒で約 $10 \mathrm{~s}$ 泊かきまぜ る.

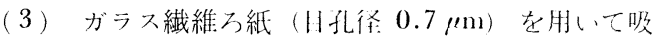
引ろ過し，ろ液の一部を乾燥した受器に受ける。

(4) $\mathrm{NO}_{2}^{-}$として $30 \mu \mathrm{g}$ 以下になる上らに液の 適量を $50 \mathrm{ml}$ のメスフラス:に正確に分取し，水を加总 て液量を $40 \mathrm{ml}$ とする。

(5) スルファニル陵溶液 $1.0 \mathrm{ml}$ を加芯てよくふり まぜ，約 $10 \mathrm{~min}$ 閏放置する。

(6) 塩酸 $\alpha$-ナフチルアミン溶液 $5.0 \mathrm{ml}$ を加之,

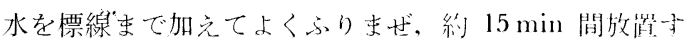
る.

（7）溶液の一部を吸収七ルに移し，波上5 $520 \mathrm{~nm}$ 付

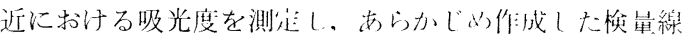
から $\mathrm{NO}_{2}{ }^{-}$量を求矿。

\section{$3.2 \mathrm{NO}_{3}-$ 標準分析方法操作}

(1) $3 \cdot 1$ (1)〜（3）の操作に從のて調製した㚣水试

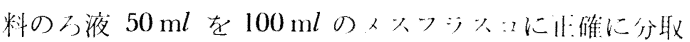
する.

(2) スルファニルアミド混命浴液 $15 \mathrm{ml}$ を加念てふ

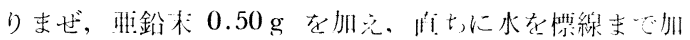
えて $1 \mathrm{~min}$ 間ふりり也゙る。

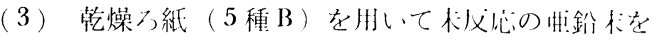

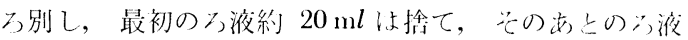
$20 \mathrm{ml} 25 \mathrm{ml}$ のメメフラ火:に报碓に分取与を.

(4) 塩酸 $(1+1) 3 \mathrm{ml}$ 反びナつチルェチレンジア

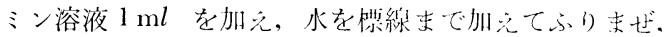

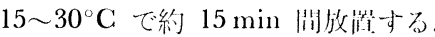

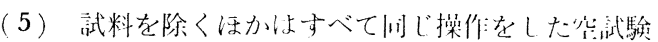

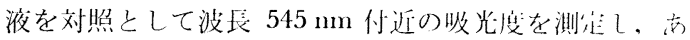
らかじぬ作成した検最線から $\mathrm{NO}_{3}$ 舅存求心。 


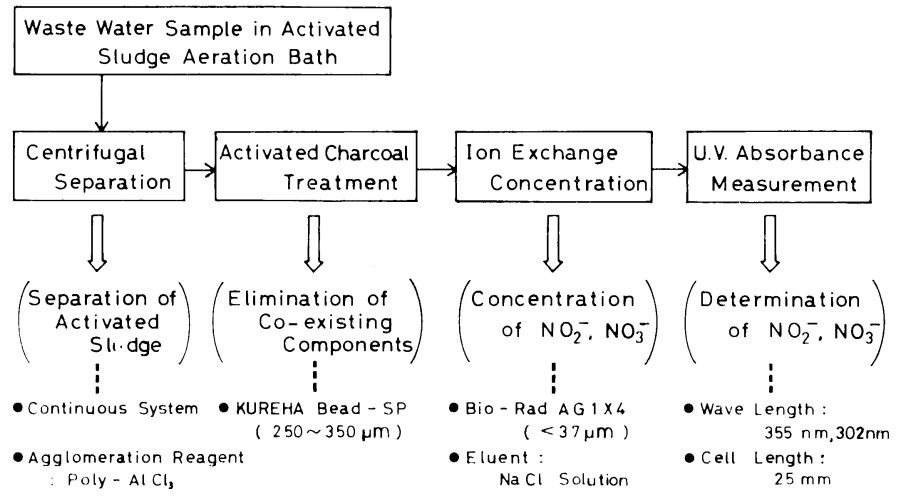

Fig. 1. Outline of the proposed method.

\section{4. 自動分析方法}

\section{1 方法原理}

確泣した $\mathrm{NO}_{2}$-反び $\mathrm{NO}_{3}{ }^{-}$の门動分析方法の基末操

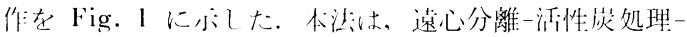
イ・ン交换処䀘－紫外吸收㛟计を基本原理とする。すな

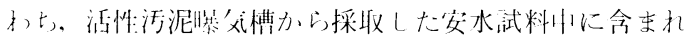
る污泥老浬絸邀心分離に上つて除去し，さらに着色成分

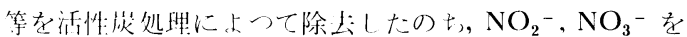
陰イォン交換樹脂に上つて吸着濃縮し，溶離液によつて 溶师さ世た㞹成分の紫外吸收を測主して両成分量を同時

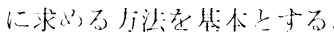

\section{$4.2 \mathrm{NO}_{2}^{-}$及び $\mathrm{NO}_{3}^{-}$の検出}

$\mathrm{NO}_{2}$ 友び $\mathrm{NO}_{3}$ - は, Fig. 2 に亦すよらにいずれる

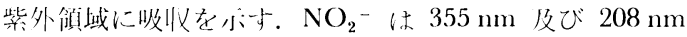
に, $\mathrm{NO}_{3}$ は $302 \mathrm{~nm}$ 反び $203 \mathrm{~nm}$ にそれぞれ相大吸収

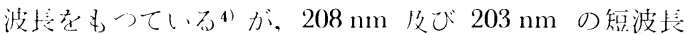

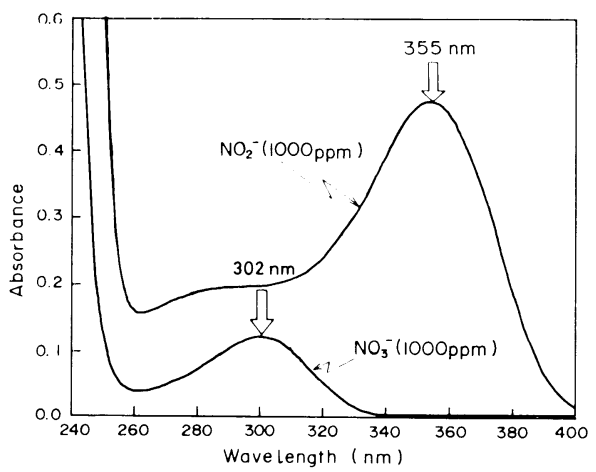

Fig. 2. Ultraviolet absorption spectra of nitrite and nitrate ions.
側の吸仪は検出感度が高い反面共存成分の干涉を受け やすい。従つて，幽成分の測定波豆としては $\mathrm{NO}_{2}{ }^{-}$は $355 \mathrm{~nm}, \mathrm{NO}_{3}$ - $302 \mathrm{~nm}$ を選定した。これらの測定波 辰に㧍いては，活性炭処理を行つた安水試料打に含ま水 る其存成分による干渉を受けることはなかつた。また， $\mathrm{NO}_{2}$ - の澌主にには $\mathrm{NO}_{3}^{-}$の干渉を全く受けることはな いが， $\mathrm{NO}_{3}^{-}$の測定には Fig. 2 からも明らかなように $\mathrm{NO}_{2}$-の吸收入ペクトルの重なりによつて正の干渉を受 ける。しかし，本分析方法では両成分の紫外吸収を直接 測定寸るのではなく，両成分をイオン交換樹脂によつて 相后に分離するために、 $\mathrm{NO}_{3}-$ の測定における $\mathrm{NO}_{2}-$ の 干渉は起こらない。

\section{3 污泥の分離}

活性活泥曝気槽液小に多星含まれる污泥の分離には, 著者らが先に開発した連続吸引る過装置4)の適用を試み たが，微細な汗泥が含まれており完全分離は困難であつ たとこで，凝集剂を併用する遠心分離法について検討 した結果, ポリ塩化アルミニウムの希薄溶液を少量添加 することにより，污泥を確実に分離でき，また㠜集剤に

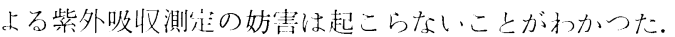
これらの結果から, 安水试料の供給, 1澄液の捕集, 伍 泥の排出を白動的に行ら連続遠心分離装置を製作して游 泥の分離を行らことにした。

$\mathrm{NO}_{2}{ }^{-}$は比較的不安起であるために，安水試料を活州 河泥嚗気槽から採取して分析するまでの経時変化につい て調べた。曝気槽から採取した安水試料を污泥を含んだ ま本放罱し，一走時閒経過ごとに遠心分離によつて污泥 を分離し，3・1，3.2 に示した分析方法に従つて $\mathrm{NO}_{2}{ }^{-}$ 及び $\mathrm{NO}_{3}$-の这量を行つた。

$\mathrm{NO}_{2}{ }^{-}$の先量結果を Fig. 3 に羊したが，採取した直

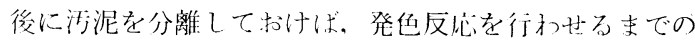




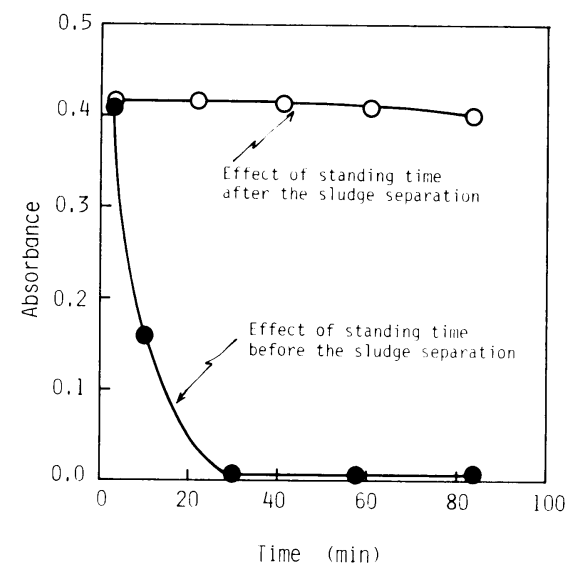

Fig. 3. Effect of standing time on nitrite ion determination in the sample solution collected from the activated sludge aeration bath.

放置時間の影響はほとんどないことがわかつた. しか し，採取後污泥を分離せずに放置して抢くと，污泥の性 状などにも関係するが，短時間で $\mathrm{NO}_{2}{ }^{-}$量が著しく減 少した. 従つて, 安水試料は採取後直ちに污泥を分離 し，なるべく迅速に分析する必要がある.

$\mathrm{NO}_{3}$ - の定量結果は, いずれの場合も $0.02 \mathrm{ppm}$ 以下 であつた。 また, 安水試料中に $0.75 \mathrm{ppm}$ 相当の $\mathrm{NO}_{2}{ }^{-}$ を添加して $40 \mathrm{~min}$ 間放置した場合， $\mathrm{NO}_{2}{ }^{-}$濃度は 0.02 $\mathrm{ppm}$ 以下に減少したが， $\mathrm{NO}_{3}{ }^{-}$濃度は増加せず 0.02 $\mathrm{ppm}$ 以下であつた。この結果から，汸泥を含んだまま 放置した場合の安水試料中の $\mathrm{NO}_{2}^{-}$は $\mathrm{NO}_{3}-$ に変化し たのではなく，脱窒反応によつて $\mathrm{N}_{2}$ などに変化したも のと考えられた.

\section{4 着色共存成分の除去}

活性污泥曝気槽から採取した安水試料は, 污泥を分離 しても黄褐色を呈しており，紫外領域で強い吸収を示す ために $\mathrm{NO}_{2}$ - 及び $\mathrm{NO}_{3}$ - 濃度を直接測走することは困 難であつた，そこで，有機化合物に起因すると思われる 着色成分を除去するために活性炭処理について検討し た。

$\mathrm{NO}_{2}^{-}$及び $\mathrm{NO}_{3}$-をほとんど含まない安水試料 100 $\mathrm{ml}$ に, 粉末活性炭 $2 \mathrm{~g}$ を加えて $10 \mathrm{~s}$ 間攪拌したのち, 溶液の紫外吸収スペクトルを測定した結果, $355 \mathrm{~nm}$ 及 び $302 \mathrm{~nm}$ に打る吸収は処理しない場合に比べて約 1/50 (吸光度約 0.01) と大幅に減少した. また，このよ らにバッチ式でなく，5.2 に述べるカラム式で行つた場 合はさらに確寒で，両波長に抢ける吸収はほとんど認め られず，安水試料中の着色成分は活性炭処理によつて十 分除去できることがわかつた.
次に活性炭による $\mathrm{NO}_{2}^{-}$及び $\mathrm{NO}_{3}^{-}$の吸着損失につ いて調べた.

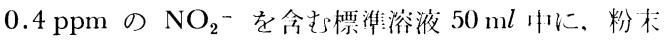
活性炭を段階的に $10 \mathrm{~g}$ 来で加えて処理した場合の $\mathrm{NO}_{2}{ }^{-}$ の回収率を調べた結果を Fig. 4 にボした， $\mathrm{NO}_{2}{ }^{-}$は湃 性炭の添加量に比例してその一部が吸着される后現象が愁 められた.

活性炭による $\mathrm{NO}_{2}^{-}$及び $\mathrm{NO}_{3}^{-}$- 吸着損失を防止一 る方法について種々検討した結果，アルカリ金属あるい はアルカリ土類金属等の塩類を溶液中に其存させる方法 が効果を示すことがわからた。これらの塩類の例にし て, 塩化ナトリウムを添加して活性:苂処理を行つた場合 の $\mathrm{NO}_{2}{ }^{-}$の回収率について検讨した結果を Fig. 4 に 併記した．溶液中に塩化ナトリウムを $1 \%$ 以は共存させ ることにより，98\%以トの $\mathrm{NO}_{2}$ をを回收することがで きた. 塩化ナトリウム以外の塩類として $\mathrm{KCl}, \mathrm{CaCl}_{2}$. $\mathrm{MgCl}_{2} \cdot 6 \mathrm{H}_{2} \mathrm{O}, \mathrm{K}_{2} \mathrm{SO}_{4}, \mathrm{KNO}_{3}, \mathrm{~K}_{2} \mathrm{CO}_{3}, \mathrm{KSCN}, \mathrm{KBr}$, $\mathrm{NH}_{4} \mathrm{Cl}$ についてもほぼ同様な結果を得た。

次に活性炭による $\mathrm{NO}_{2}{ }^{-}$の吸着と溶液の $\mathrm{pH}$ との関 係について調べた. $0.4 \mathrm{ppm}$ の標準 $\mathrm{NO}_{2}{ }^{-}$溶液 $50 \mathrm{ml}$ 中に塩化ナトリウム $0.5 \mathrm{~g}$ を添加し, 塩酸及びアンモ二 ア水を用いて溶液の $\mathrm{pH}$ を段階的に変元, $1 \mathrm{~g}$ の活州:

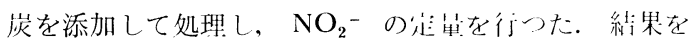
Fig. 5 に示したが, $\mathrm{NO}_{2}^{-}$の活性炭による收着垷象は 溶液の $\mathrm{pH}$ の影響が顕著であり，盐化ナトリウムなどの 塩類を添加し，なお $\mathrm{pH}$ を 4.5 以に:にする必崖がある ことがわかつた。

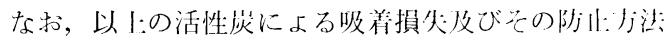

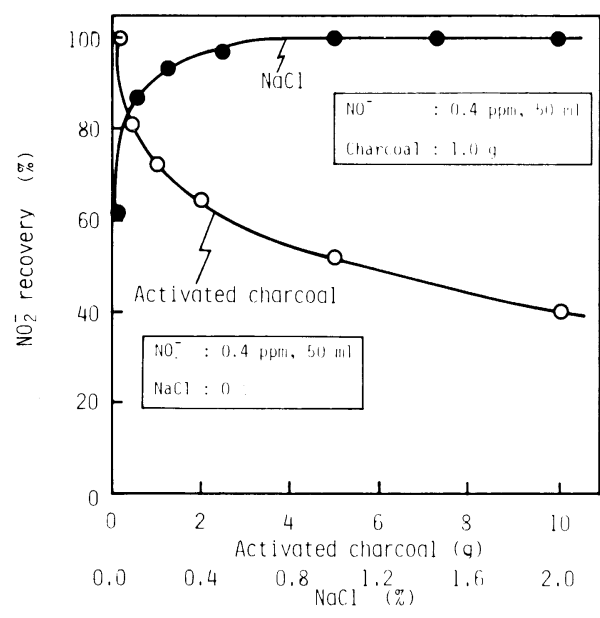

Fig. 4. Relation between nitrite ion recovery and activated charcoal content and sodium chloride concentration. 


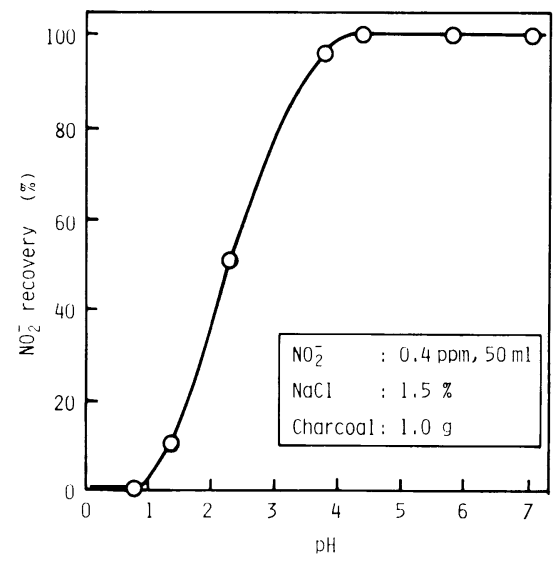

Fig. 5. Relation between nitrite ion recovery and $\mathrm{pH}$ of waste water in activated charcoal treatment.

における効果については $\mathrm{NO}_{2}$-を中心に述べたが $\mathrm{NO}_{3}^{-}$ の場命についてもほとんど同じ結果を得た。

次に実際試料に扣忛る $\mathrm{NO}_{2}^{-}$の活性炭による吸着損 失について調べた。汗泥を除去し, 標準 $\mathrm{NO}_{2}{ }^{-}$及び $\mathrm{NO}_{3}$ - 溶液を添加した安水試料を対象に, 着色成分によ る空試験の影響を抑えるために少量の試料を希釈して用 いて直接起舁した場合と, 塩類の添加や $\mathrm{pH}$ 調整を行わ ずにその束活性炭処理して足量した場合との両成分の 企量結果を比較検沽した。 その結果, 両者の定量結果は 活注一致した. $\mathrm{NO}_{2}^{-}$及び $\mathrm{NO}_{3}^{-}$を添加した安水試料 は, 呈色時吸光度。着色成分に起因する空試験吸光度と の差が明瞭なため, 前者の走量值は真值に近い值を示し ていると考えられる。従つて, 実際の安水試料について は, 直接活性炭で処理しても $\mathrm{NO}_{2}{ }^{-}$及び $\mathrm{NO}_{3}{ }^{-}$の吸着 損失は起らないといえる。これは，対象とした儤気槽中 の安水は海水で希积されており, 約 $1.5 \%$ 以上の塩化ナ トリウムなどの塩類を含み，また $\mathrm{pH}$ も約 7 に制御され ているためと考えられる。

\section{$4.5 \mathrm{NO}_{2}^{-}, \mathrm{NO}_{3}{ }^{-}$のイオン交換濃縮及び相互分離}

微量の $\mathrm{NO}_{2}-$ 及び $\mathrm{NO}_{3}$ をを定量するために，イオン 父換樹脂を用いる濃縮及分離方法について検討した. ての結果, $\mathrm{NO}_{2}^{-}$及び $\mathrm{NO}_{3}-$ は陰イオン交換樹脂に容 易に吸着でき，末た塩化ナトリウムを含も溶離液によつ て产易に浴出できることがわかつた，標準 $\mathrm{NO}_{2}{ }^{-}$溶液 $100 \mathrm{ml}$ を陰イオン交換樹脂約 $2 \mathrm{~g}$ を充填したカラム(内 径 $9 \mathrm{~mm} \phi$, 惊さ $100 \mathrm{~mm}$ ) に約 $10 \mathrm{ml} / \mathrm{min}$ の流量で送 り込み，次に篮化ナトリウム溶液 $(5 \%)$ を $10 \mathrm{ml} / \mathrm{min}$ の流星で注入して得た溶出液 $10 \mathrm{ml}$ を捕集し, $\mathrm{NO}_{2}^{-}$

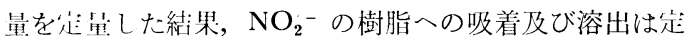

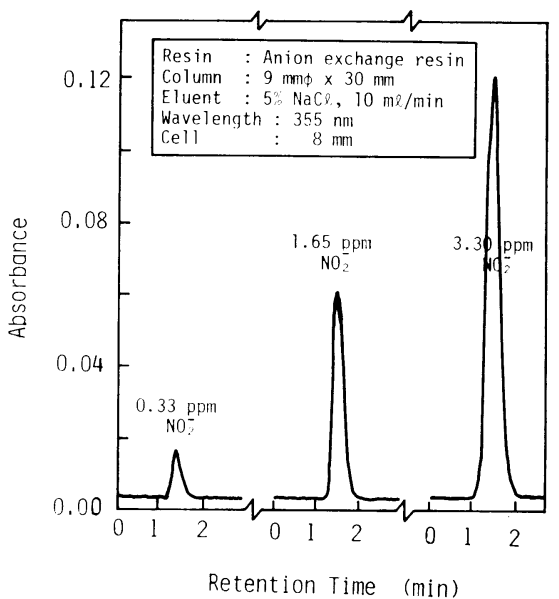

Fig. 6. Elution curves of nitrite ion absorbed over ion exchange resin.

量的に行われ，約 10 倍に濃縮することができた. この 溶出液を分光光度計のミクロフローセル（光路長 $8 \mathrm{~mm}$, 内容積 $8 \mu l$ ) に送り込み， $\mathrm{NO}_{2}^{-}$-の $355 \mathrm{~nm}$ に打ける吸 収を連続的に測定する方法をとつた場合には，Fig. 6 に 示すよらにさらに微量域の定量が可能になることがわか つた。 また，樹脂に吸着された $\mathrm{NO}_{2}^{-}$及び $\mathrm{NO}_{3}^{-}$は， 樹脂柱を約 $100 \mathrm{~mm}$ として，塩化ナトリウム溶液 (5\%) を $10 \mathrm{ml} / \mathrm{min}$ の流量で送り込むことによつて，最初に $\mathrm{NO}_{2}^{-}$が，とのあとに $\mathrm{NO}_{3}^{-}$が溶出し，両成分が相互 に分離できることがわかつた (Fig. 12).

\section{5. 連続測定システム}

4. で述べた自動分析方法を基本に $\mathrm{NO}_{2}$ - 及び $\mathrm{NO}_{3}-$ 濃度の 同時連続測定 システムを開発した. 開発したシ ステム全体の概略を Fig. 7 に，自動分析装置の概観を Photo. 1 に示した. 本システムは污泥分離部, 活性炭処 理部，イオン交換濃縮部，紫外吸収測定部及び自動制御 部から構成される.

\section{1 污泥分離部}

活性污泥曝気槽から採取した安水試料中の污泥の分離 は，市販の高速連続遠心分離機に試料供給管，污泥排出 管，洗浄液供給管，これらの管の上下機構，試料及び凝 集剂供給ポンプ，污泥排出ポンプ，回転数自動制御機構 及び全操作の自動制御機構を付設して製作した污泥連続 分離装置を用いて行つた。本装置の主要部及び分離方法 の概略を Fig. 8 に示した.

本装置による污泥分離の操作は次のように行う。

（1）活性污泥曝気槽からポンプによつて採取した安 水試料を $24 \mathrm{ml} / \mathrm{min}$ の流量で，また凝集剤を $0.8 \mathrm{ml} /$ 


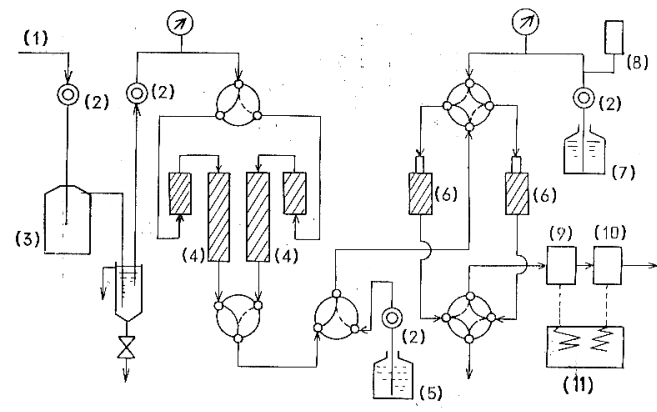

(1) Sample, (2) Pump, (3) Centrifugal separator, (4) Activated charcoal column, (5) Water, (6) Ion exchange column, (7) $\mathrm{NaCl}$ solution, (8) Damper, (9) UV detector $(355 \mathrm{~nm})$, (10) UV detector $(302 \mathrm{~nm})$, (11) Recorder

Fig. 7. Schematic diagram of the developed system for measuring continuously concentration of nitrite and nitrate ions in the activated sludge aeration bath.

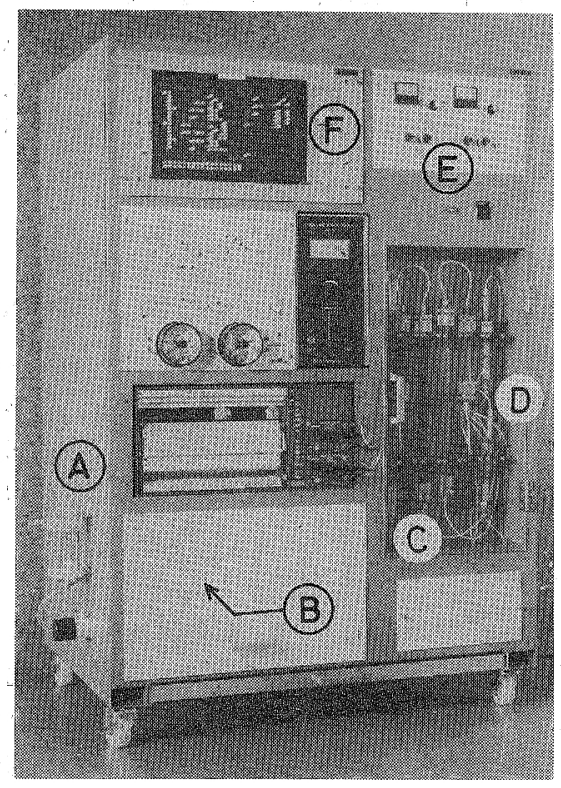

Photo. 1. The developed apparatus for automatic determination of nitrite and nitrate ions. A : Sample injector connected, to centrifuge, $\mathrm{B}:$ Pump, $\mathrm{C}$ : Activatid charcoal column, D : Ion exchange column, E: Ultraviolet detector, $\mathrm{F}$ : Sequence programmer

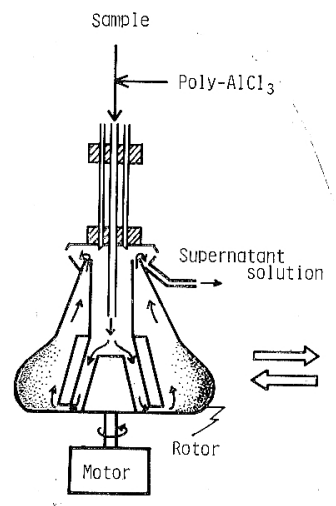

Sample Separation

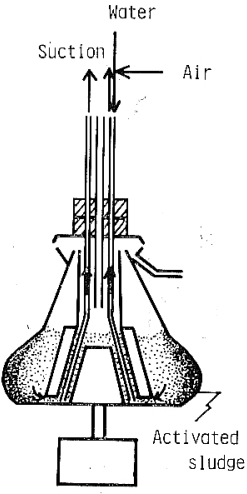

Sludge Discharge
Fig. 8. Explanation of centrifugal sample separation system from accomppanying activated sludge.

min の流量で遠心分離機のローター内に供給するととも Kローターを２000 rpm まで徐々に回転さ让る。

(2) ローター内に安水試料が洅たされると, 試料の 供給量に見合つた流量で上澄液が捕集され，分析装置本 体に送ら机る。

(3): 約 $30 \mathrm{~min}$ 後飞ローターの回転を徐々に停止さ せ，污泥排出管及び洗浄液供給管をエアーシリンダーの 動作によつてローター内にそら入する。

（4）污泥排出ポンプを作動させ，ローター内に推積 した污泥を吸引して排出する。

(5)：洗浄液及び安水試料をロ-タ一内K供給し，空 気老吹き込んてローター内を攪抖洗浄したのちポンプに よつて污泥を吸引して排出する.

（6）污泥排出管及び洗浄液供給管をローター内から 引き上げて，再び上記 (1)の操作にもどつて繰り返して 行ら.

これらのずべての操作は, あらかじめ定めた操作プロ グラムにしたがつて自動的に制御さ朊る，安水試料を $24 \mathrm{ml} / \mathrm{min}$ の流量で供給した場合は，試料中に含まれる 污泥の量が多いために約 $30 \mathrm{~min}$ 後にはFig. 8 右図の ようにローター内に污泥が堆積した。 このままの状態で 汸泥の分離操作 (Fig. 8 左図) を続行すると, 上澄液认 污泥の一部が混入するために，ローターの回転を止めて 污泥を排出することにした。凝集剤を用いることによつ て污泥を確実に沈降させて分離することができたが，污 泥がローター内で固化する現象がみられたため，上述の ように洗浄液及び空気を吹き込むなざの污泥の剝離操 作を行う必要があつたまた，口ータ一内容積が約 600 $\mathrm{m} l$ と大きいために安水試料を供給してから約 $10 \mathrm{~min}$ 間経過しないと上澄液の些出を開始しなからたが，分析 
装消:本体の+ンゾリングは約 $10 \mathrm{~min}$ 間に 1 问で，液量 も $20 \mathrm{ml}$ であるたか䦌題はなかつた。しかし，分析装筧 の+ン・リング界くしたり，分析頻度を多くする場

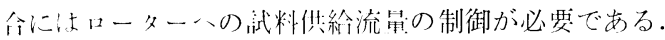

ローターの叫伝数を $2000 \mathrm{rpm}$ 以トにし， |記操作に

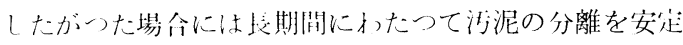
して行らこよができた。

\section{2 活性炭処理部}

污泥を分離した安水試料は，湖性炭を充填した力ラ 公起通して着色成分の除去を行つた。 カラムは内径 15 $\mathrm{mm} \phi \dot{\varphi}$, 垃さ $100 \mathrm{~mm}$ 及び内径 $15 \mathrm{~mm} \phi$, 長さ $300 \mathrm{~mm}$ の 2 本のガラ久製カラんに精状活性炭を充填し，この 2 本を接続して用いた１本月の短かいカラムは試料溶液 をトお斿供給し，2本月のカラムはト方から供給する 上うにした。これは，遠心分離による污泥の分離が不完 金で試料に濁りが活のた場合に，1本目のカラムでこの

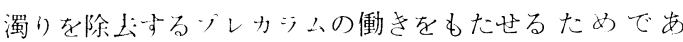
る.このカラムおj式で活性炭処理を行つた場合は，バッ チ式で行うよりも処理は確奏で，カラムを出た溶液の $355 \mathrm{~nm}$ 及び $302 \mathrm{~nm}$ における吸収はほとんど認めら れなか一た。また，污泥を分離した曝父槽中安水試料を $10 \mathrm{ml} / \mathrm{min}$ の流星で約 1 力月間捙続して供給しても脱 色效果は低卜せず，上期間使用できることを確認した。

\section{3 イオン交換濃縮部}

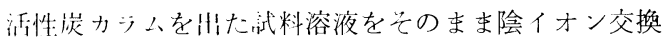
カシムに㾞り込んで $\mathrm{NO}_{2}^{-}$及び $\mathrm{NO}_{3}{ }^{-}$の分離及び濃縮

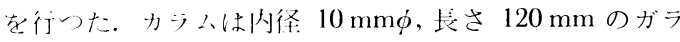
久製力シ之に陰イォン交換樹脂を $100 \mathrm{~mm}$ の高さ市で 光填したものを䏘いた。倵料抽塩化物イオン $\left(\mathrm{Cl}^{-}\right)$ を多早含却場命には，この Cl-の影響で $\mathrm{NO}_{2}$ - 及び

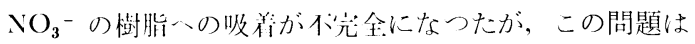
樹脂柱:をはくなることによつて解汱できた．Cl一が塩化 ナトリウムとにて約 $1.5 \%$ 禽有されている安水試料を $10 \mathrm{ml} / \mathrm{min}$ の流㫙で $2 \mathrm{~min}$ 閒, 与なおり, $20 \mathrm{ml}$ を送り

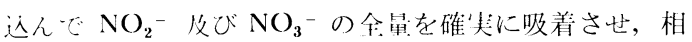

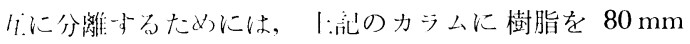
以はの的さになるように允填する必要があつた。サンプ リング界を增㞦してらに微星域の走量を行らために は，力ラんの樹脂柱をより主くする必要がある。

樹脂に收着捕促された $\mathrm{NO}_{2}^{-}$收び $\mathrm{NO}_{3}^{-}$は, 塩化ナ トリウム浴離液 $(5 \%)$ を $10 \mathrm{ml} / \mathrm{min} の$ 这量で送り込 んで浴计させた。浴離液の主流量性は告量精度に影響すす るために重装であるが，Fig. 7 に示したよらにダンバー を用いてボンンのの脈動を吸収させ， $\mathrm{NO}_{2}^{-}$及び $\mathrm{NO}_{3}^{-}$ の溶離操作を行わない時でもポンプは常時作動させ，溶
離液はイオン父換カラムと间じ負荷に調整した別のカラ ムに流して流量の安走化をはかつた。また，溶離液の流 晕を $10 \mathrm{ml} / \mathrm{min}$ より羊くした場合には，検出器の感度 を高めている関係で，カラム中に残留していた試料溶液 と溶離液之が混ざり合うことに起因するノイズピークと $\mathrm{NO}_{2}^{-}$のピークとが重なり， $\mathrm{NO}_{2}^{-}$のピークを明確に検 出することができなくなつた。

\section{4 紫外吸収測定部}

イオン交換カラムを出た溶出液は, 紫外検出器のフロ 一七ル (内径 $3 \mathrm{~mm} \phi$, 光路長 $25 \mathrm{~mm}$ ) 中を $10 \mathrm{ml} / \mathrm{min}$ の流量で流れる間に $355 \mathrm{~nm}$ 及び $302 \mathrm{~nm}$ 付近における $\mathrm{NO}_{2}{ }^{-}, \mathrm{NO}_{3}{ }^{-}$の吸光度が測定され, 2 ペン式記録計に 記録される. 紫外検出器はキセノンランプ $(75 \mathrm{~W})$ を光 源とし， $355 \mathrm{~nm}$ 及び $302 \mathrm{~nm}$ の 2 波長を金属干渉フィ ルター(波長幅 $13 \sim 16 \mathrm{~nm}$ ) で分光し，ダブルビーム方式 で光電管によつて検出する高感度紫外線吸収計を試作し て用いた，本検出器は光路長 $10 \mathrm{~mm}$ の吸収セルを用い た場合に, 0.025 吸光度フルスケールの感度にまで設定 でき，0.05 吸光度フルスケールに設定した場合の 355 $\mathrm{nm}$ に拈けるノイズ幅は $\pm 0.5 \%$ 以下で，非常に低い吸 光度を高感度で長時間安定して測定することができた。

\section{5 自動制御部}

以上述べた連続測定システムの各部の制御は，シーケ ンスプログラマー（和泉電機製，PRG 2018T 型）にめ らかじめ設定した操作プログラムにしたがつて下記のよ らに操作される。

（1）活性污泥曝気槽から採取した安水試料は，污泥 連続分離装置により，5.1 に述べた操作プログラムにし たがつて污泥が自動的に分離除去され，上澄液が分析装 置に供給される。

（2）上澄液を試料供給ポンプによつて吸い上げ, $10.0 \mathrm{ml} / \mathrm{min}$ の一定流量で $2 \mathrm{~min}$ 間活性炭カラムに送 り込久, 着色成分を吸着除去する。

（3）活性炭カラムを出た試料溶液は，3 回の流路切 替器を通つてイオン交換カラムに送り込まれ， $\mathrm{NO}_{2}^{-}$文 び $\mathrm{NO}_{3}$ - を吸着捕促させ, 溶液は系外に排出される.

（4）上部 (2)及び (3)の操作を行つている間に，溶 離液供給用ポンプによつて塩化ナトリウム溶液を 10.0 $\mathrm{ml} / \mathrm{min}$ の流量で負荷を同じにした別のイオン交換カラ ムに送り込み，流量の安定化をはかるとともに，この液 を紫外検出器に導入して検出器のベースラインを調整す る.

（5）次に流路を切り替え，溶離液をイオン交換カラ 么に送り込み, $\mathrm{NO}_{2}^{-}$及び $\mathrm{NO}_{3}^{-}$を溶出させる.

(6) 溶出液が紫外検出器のフローセル中を通過する 
間に， $355 \mathrm{~nm}$ 及び $302 \mathrm{~nm}$ に和ける吸光度が連続的に 測定され，両成分によるピークが記録される。このピー ク高さから，あらかじめ作成した検量線をもとに両成分 濃度を求める.

（7）溶出操作を約 $5 \mathrm{~min}$ 間行つたのち，各流路を切 替兄て溶離液はもとのイオン交換カラムを流れるように し，一定流量を保持させておく。

（8）洗浄液ポンプによつて，洗浄液をイオン交換力 ラムへ $10 \mathrm{ml} / \mathrm{min}$ の流量で約 $3 \mathrm{~min}$ 間送り込み, カラ ム中に残留していた溶離液を排出する。このあと再び上 記 (2)の操作にもどつて繰り返して行う.

\section{6. 適用結 果}

\section{1 定量感度及び精度}

本自動分析装置を用い，塩化ナトリウム $1.5 \%$ を含む $\mathrm{NO}_{2}-$ 及び $\mathrm{NO}_{3}-$ の標準溶液 $20.0 \mathrm{ml}$ を対象に作成し た検量線を，それぞれ Fig. 9，Fig. 10 亿示した.いず 孔も直線性は良好で, $\mathrm{NO}_{2}^{-}$は $0.1 \mathrm{ppm}$ 程度まで, $\mathrm{NO}_{3}-$ は $1 \mathrm{ppm}$ 程度までの微量を高感度で, 再現性よ く定量することができた．また，イオン交換カラムの樹 脂柱を長くして試料供給量を多くすることにより，さら に微量域の定量が可能であつた。

\section{2 共存成分による干渉}

対象とした安水試料中には, フェノール類, 硫化物, チオ硫酸，油分等の各イオン及びその他着色成分など多 くの共存成分が含まれているが，本法では活性炭及びイ オン交換処理を行らために，これらの共存成分による干 渉はみられなかつた。 また， $\mathrm{NO}_{3}-$ の定量に扮いて子紫 外吸収スペクトルが重なる $\mathrm{NO}_{2}-$ は，イオン交換カラ ムによつて相互に分離できたためにその干渉も防ぐこと ができた (Fig. 12).

\section{3 測定チャート}

本装置によつて得られた $\mathrm{NO}_{2}$ - 及び $\mathrm{NO}_{3}$-の測定于 ャートの例を Fig. 11，Fig. 12 に示した. イオン交換 カラムから溶出した $\mathrm{NO}_{2}^{-}$及び $\mathrm{NO}_{3}^{-}$は, 図示したよ うとシャープなピークを形成し，長期間安定して測定す ることができたＦig. 12 の $\mathrm{NO}_{3}$-の測定チャートは, $6 \mathrm{ppm}$ の $\mathrm{NO}_{2}$ - 及び $1.5 \%$ の塩化ナトリウムを共存さ せた標準 $\mathrm{NO}_{3}{ }^{-}$溶液 $20.0 \mathrm{ml}$ を対象に分析した結果で ある.イオン交換カラムによつて $\mathrm{NO}_{2}^{-}$は $\mathrm{NO}_{3}^{-}{ }^{-}$上り も早く溶出し, 両者は相互に分離した状態で検出され, 互に干渉し合うことがなかつた。したがって， $\mathrm{NO}_{2}^{-}$濃 度が高い場合は，302 nm の一波長だけで両成分の同時 定量が可能である.

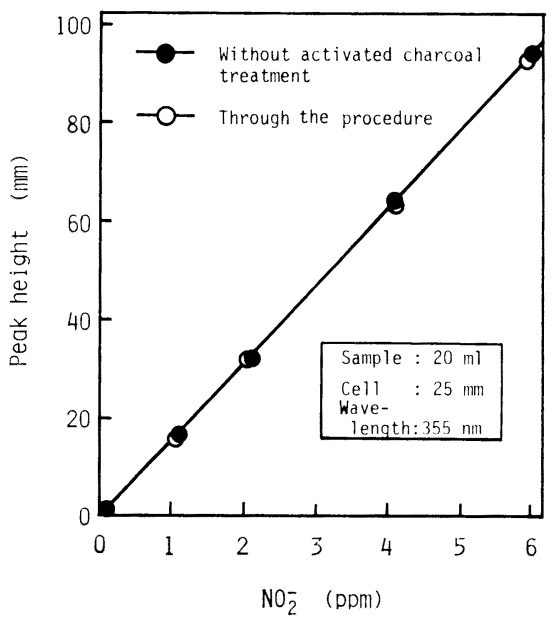

Fig. 9. Calibration curves for nitrite ion determination.

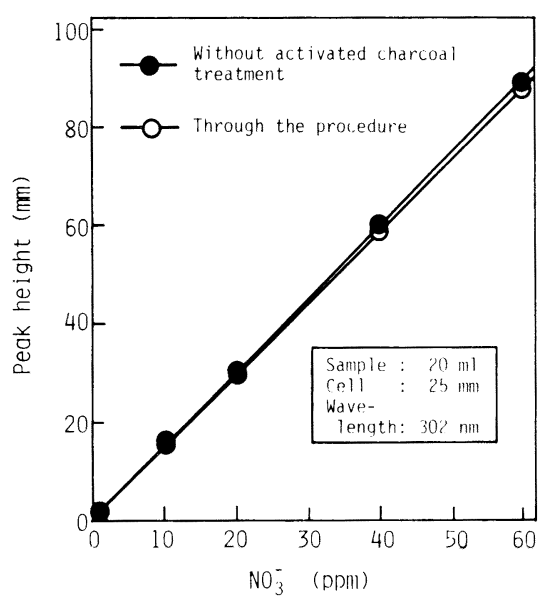

Fig. 10. Calibration curves for nitrate ion determination.

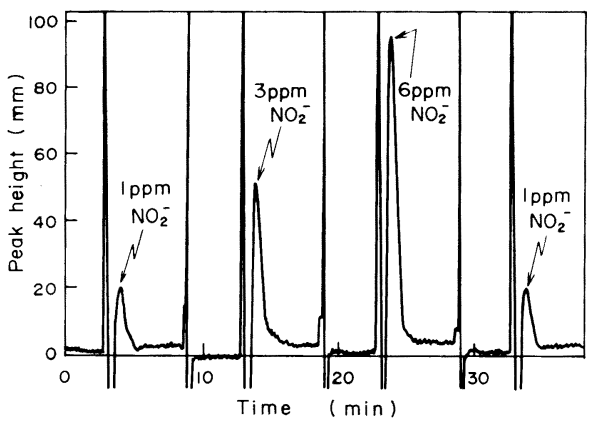

Fig. 11. Recording charts of determination of nitrite ion concentration. (Wavelength : $355 \mathrm{~nm}$ ) 


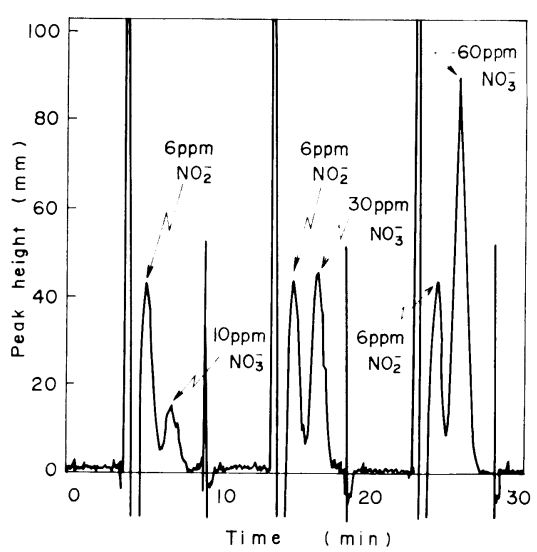

Fig. 12. Recording charts of determination of nitrate ion concentration. (Wavelength : $302 \mathrm{~nm}$ )

\section{4 定量結果}

活性活泥曝気槽から採取した安水試料中の $\mathrm{NO}_{2}^{-}$濃 度の定量絬果の一例を，丁操作標準分析法 $(3 \cdot 1)$ による 定量結果と比較して Table 1 に示した。本装置による 定量值は, 手操作による分量优とよく一致した結果が得 られた。

また，问様に $\mathrm{NO}_{3}{ }^{-}$の这暈をを行つたが，安水試料中 の $\mathrm{NO}_{3}{ }^{-}$濃度は低く定㫣さ扎なからたので，この試料 溶液に慓準浴液を添加して合成した武料を対象に定量し た結果を Table 2 にふした. 本装置による定量值は,

Table 1 Analytical results of nitrite ion in the activated sludge aeration bath.

\begin{tabular}{ccc}
\hline Sample & Proposed method & Manual method ${ }^{\dagger}$ \\
\hline $\mathrm{A}$ & $0.30 \mathrm{ppm}$ & $0.32 \mathrm{ppm}$ \\
$\mathrm{B}$ & $0.85 \mathrm{ppm}$ & $0.83 \mathrm{ppm}$ \\
$\mathrm{C}$ & $2.62 \mathrm{ppm}$ & $2.65 \mathrm{ppm}$ \\
$\mathrm{D}$ & $5.45 \mathrm{ppm}$ & $5.45 \mathrm{ppm}$ \\
\hline$+\alpha$-Naphtylamine-sulfanilic acid spectrophotometric method is \\
applied after the activated charcoal treatment, as shown in \\
3.1
\end{tabular}

Table 2 Analytical results of nitrate ion in the actual sample and synthetic samples

\begin{tabular}{|c|c|c|}
\hline Sample & Proposed method & Manual method $t$ \\
\hline Actual* A & $0.0 \mathrm{ppm}$ & $<0.02 \mathrm{ppm}$ \\
\hline Synthetic** A & $1.5 \mathrm{ppm}$ & $1.2 \mathrm{ppm}$ \\
\hline B & $5.0 \mathrm{ppm}$ & $5.5 \mathrm{ppm}$ \\
\hline C & $10.5 \mathrm{ppm}$ & $10.2 \mathrm{ppm}$ \\
\hline
\end{tabular}

$\dagger$ Naphtylethylene diamine spectrophotometric method is applied after the activated charcoal treatment and the reduction by zinc, as shown in 3.2.

* Solution in the activated sludge aeration bath.

** Mixed solution of the above solution and the standard nitrate ion solution.
手操作標準分析法 $(3 \cdot 2)$ による噩量値とほぼ一致した.

以上のよらに, 開発した $\mathrm{NO}_{2}{ }^{-}, \mathrm{NO}_{3}{ }^{-}$濃度の連続測 起システムによれば，活性污泥曝気槽安水中に含まれる $0.1 \mathrm{ppm}$ までの微量 $\mathrm{NO}_{2}$ - 及び $1 \mathrm{ppm}$ までの $\mathrm{NO}_{3}^{-}$ を同時に $10 \mathrm{~min}$ 間隔で, 間けつ連続的に全自動操作に よつて分析することができ, 安水活性污泥処理の操業管 理に十分失用することができた。

\section{7. 結言}

安水活性污泥処理の安企化操業技術の確立に関係し て, 活性活泥儤父槽液中に発生する微量 $\mathrm{NO}_{2}{ }^{-}$及び $\mathrm{NO}_{3}$ - 濃度の同時連続測走力法及びシステムを開発し た. 本法は安水試料中の共存成分を分離後に $355 \mathrm{~nm}$ 及 び $302 \mathrm{~nm}$ の紫外吸收を直接測走する力法で，遠心分離 (污泥の除去) -活性炭処理 (着色成分等の除去) -イオン交 換処理 $\left(\mathrm{NO}_{2}{ }^{-}, \mathrm{NO}_{3}{ }^{-}\right.$の濃縮及び相互分離)-紫外吸収 検出 $\left(\mathrm{NO}_{2}^{-}, \mathrm{NO}_{3}{ }^{-}\right.$濃度の測定）を基本原理とする.

本連続測定システムを開発する基礎実験過程でとくに 次のよらな点について明らかにした。

（1）曝気槽から採取した安水試料は，短時間で污泥 による脱窒反応を受け， $\mathrm{NO}_{2}^{-}$及び $\mathrm{NO}_{3}^{-}$が分解する ために採取後は污泥を直りに分離する必要がある.

（2）污泥の連続分離は，万過方式よりも凝集剂を用 いる遠心分離方式が適している。

(3) 着色成分等の除去は活性炭処理が有効である.

$\mathrm{NO}_{2}{ }^{-}$及び $\mathrm{NO}_{3}{ }^{-}$の活性炭入の吸着は, アルカリ金属 イオン等を共存させ, かつ溶液 $\mathrm{pH}$ を 4.5 以上にする ことによつて防止できる。

(4) $\mathrm{NO}_{2}{ }^{-}, \mathrm{NO}_{3}{ }^{-}$は陰イオン交換樹脂に容易に吸 着捕捉でき，また塩化ナトリウム溶液によつて容易に溶 出でき，両成分の濃縮及び相互分離が行える.

(5) 安水試料昍の $\mathrm{NO}_{2}^{-}$及び $\mathrm{NO}_{3}^{-}$の紫外吸收測 这波舆は，それぞれ $355 \mathrm{~nm}, 302 \mathrm{~nm}$ が適している。

開発した連続測定システムは, 活性污泥曝父槽からポ ンプによつて安水試料を送り込めば，各操作はあらかじ め設定したプログラムにしたがつてすべて自動的に箺施 される、本システムによれば，安水试料中の $0.1 \mathrm{ppm}$ までの微量の $\mathrm{NO}_{2}$ - 及び $1 \mathrm{ppm}$ までの $\mathrm{NO}_{3}$ - 濃度を10 min 間隔で間けつ連続的に同時に自動測定することがで き, 安水活性污泥処理の操業管理に十分実用できた.

\section{交献}

1) JIS K 0102-1971 「工場排水試験法」

2) $L . J$. Kamphake, $S . A$. Hannah and $J . M$. Cohen : Water Research, 1 (1967), p. 205

3 ) JIS K 0104-1974「排ガス中窒素酸化物分析法」

4) 松本龍太虾，山口直治，小野昭紘：鉄と鋼，66 (1980) 5, p. 539 